University of Nebraska - Lincoln

DigitalCommons@University of Nebraska - Lincoln

US Army Research

U.S. Department of Defense

2010

\title{
Toxicity and bioaccumulation of TNT in marine fish in sediment exposures
}

Guilherme R. Lotufo

US Army Engineer Research and Development Center, guilherme.lotufo@usace.army.mil

William Blackburn

US Army Engineer Research and Development Center

Sydney J. Marlborough

Louisiana State University

John W. Fleeger

Louisiana State University

Follow this and additional works at: https://digitalcommons.unl.edu/usarmyresearch

Part of the Operations Research, Systems Engineering and Industrial Engineering Commons

Lotufo, Guilherme R.; Blackburn, William; Marlborough, Sydney J.; and Fleeger, John W., "Toxicity and bioaccumulation of TNT in marine fish in sediment exposures" (2010). US Army Research. 136.

https://digitalcommons.unl.edu/usarmyresearch/136

This Article is brought to you for free and open access by the U.S. Department of Defense at DigitalCommons@University of Nebraska - Lincoln. It has been accepted for inclusion in US Army Research by an authorized administrator of DigitalCommons@University of Nebraska - Lincoln. 


\title{
Toxicity and bioaccumulation of TNT in marine fish in sediment exposures is
}

\author{
Guilherme R. Lotufo $^{\mathrm{a}, *}$, William Blackburn ${ }^{\mathrm{a}}$, Sydney J. Marlborough ${ }^{\mathrm{b}}$, John W. Fleeger ${ }^{\mathrm{b}}$ \\ a US Army Engineer Research and Development Center, 3909 Halls Ferry Road, Vicksburg, MS 39180, USA \\ ${ }^{\mathrm{b}}$ Department of Biological Sciences, Louisiana State University, Baton Rouge, LA 70803, USA
}

\section{A R T I C L E I N F O}

\section{Article history:}

Received 1 September 2009

Received in revised form

2 February 2010

Accepted 6 February 2010

Available online 2 March 2010

\section{Keywords:}

Explosives

TNT

Sediment

Bioaccumulation

Cyprinodon variegatus

Hypsoblennius ionthas

\begin{abstract}
A B S T R A C T
The bioaccumulation potential and toxicity of 2,4,6-trinitrotoluene (TNT) spiked to sediment was evaluated in juvenile sheepshead minnows (JSHM, Cyprinodon variegatus) and adult freckled blennies (FB, Hypsoblennius ionthas). The JSHM were exposed for 4 days in the presence or absence of a mesh separating fish from sediment. FB were exposed to sediment for 7 days. During the 24-day storage period $\left(4^{\circ} \mathrm{C}\right)$, extensive transformation of spiked TNT occurred and concentrations are expressed as the sum of TNT, aminodinitrotoluenes and diaminonitrotoluenes (SumTNT), on a dry weight basis. SumTNT in the overlying water, not exchanged during exposure, increased gradually. Survival was high ( $\geq 90 \%)$ for JSHM exposed to $7 \mathrm{mg} \mathrm{kg} \mathrm{k}^{-1}$ and FB exposed to up to $260 \mathrm{mg} \mathrm{kg}^{-1}$. All SHM died after $24 \mathrm{~h}$ exposure to $340 \mathrm{mg} \mathrm{kg}^{-1}$. Isolation from sediment did not significantly affect water concentrations or decrease bioaccumulation. Uptake from contact to sediment was likely negligible and bioaccumulation was from the overlying water. The feeding rate of FB exposed to $1700 \mu \mathrm{mol} \mathrm{kg}{ }^{-1}$ sediment suspended in water for 24-h was significantly reduced by $50 \%$.
\end{abstract}

Published by Elsevier Inc.

\section{Introduction}

Release of explosive compounds to the environment has been documented for manufacturing, handling, and disposal operations at military sites throughout the world, resulting in contamination of surface and ground waters, soils, and sediments (Talmage et al., 1999). Contamination of sediments with explosives is also associated with the presence of unexploded ordnance and dumped ammunition in marine environments (Darrach et al., 1998; Rodacy et al., 2000; Dave, 2003; Ek et al., 2006). The nitroaromatic explosive, TNT, was among the most abundantly produced explosive manufactured worldwide over the last century. Its release to surface water and groundwater has been mostly from runoff and leaching from storage and disposal areas, as well as release from receiving lagoons at munitions production and processing facilities (Fuchs et al., 2001). Reduction of the nitro-groups to amino-groups typically follows introduction of TNT to soils (Pennington and Brannon, 2002) and sediments (Lotufo et al., 2009). The major aminated metabolites of TNT are 2-aminodinitrotoluene (2-ADNT) or 4-aminodinitrotoluene (4-ADNT) and 2,4-diaminonitrotoluene (2,4- DANT) or 2,6-diaminonitrotoluene (2,6-DANT) (Elovitz and Weber, 1999; Pennington and Brannon, 2002).

\footnotetext{
The US Navy's Environmental Sustainability Development to Integration Program and the Installation Restoration Research Program of the US Army Corps of Engineers supported this research.

* Corresponding author. Fax: +16016342120.

E-mail address: guilherme.lotufo@usace.army.mil (G.R. Lotufo).
}

Trinitrotoluene and its major transformation products have demonstrated toxic effects on fish and benthic invertebrates as reviewed in Nipper et al., 2009 and Lotufo et al., 2009. Therefore, the presence of those compounds in aquatic systems may pose ecological risks and could represent a significant remediation challenge (Robidoux et al., 2003).

The toxicity and bioaccumulation of sediment-associated TNT and its transformation products have been reported for a variety of invertebrates (Lotufo et al., 2009). However, reports of bioaccumulation and toxicity of sediment-associated explosives to fish has not been reported in the available literature.

Fish can bioaccumulate sediment-associated contaminants through direct uptake from benthic prey, directly from bed sediment particles through ingestion or dermal contact, and also from the overlying water via suspended sediment particles or the dissolved phase. Direct contact with sediment surfaces resulting in uptake of hydrophobic organic contaminants in benthic fish has been reported (e.g., Hellou et al., 1994, 1995; Smith et al., 1996) and therefore could be a potential route of exposure for explosive compounds.

The objective of the present study was to evaluate the potential for sediment-associated TNT to bioaccumulate and promote lethal effects in two species of fish, sheepshead minnows (SHM, Cyprinodon variegatus) and freckled blennies (FB, Hypsoblennius ionthas). The contribution of direct uptake from contact with the sediment surface relative to the contribution from uptake from overlying water was investigated. Exposed organisms were evaluated for the presence of TNT and its transformation products in 
their tissues. Due to the tendency for TNT to rapidly undergo transformation to products that are not typically identified by chemical analysis or that covalently bind to sediment and tissues (Rosen and Lotufo, 2005), radiolabeled TNT was used in one of the experiments described here, for which a combination of radioactive tracing and traditional chemical analysis was used to better evaluate the fate of TNT in both sediment and tissues. Toxicity data, expressed as sediment, overlying water, and whole body concentrations reported here, are useful for ecological risk assessments of explosives and unexploded ordnance contamination in marine and estuarine environments.

\section{Material and methods}

\subsection{Experimental organisms}

Laboratory-cultured 8-week-old juvenile SHM (JSHM) were purchased from Aquatic BioSystems (Fort Collins, CO) and shipped overnight to the US. Army Corp of Engineer's Research and Development Center, Vicksburg, MS, approximately one week before exposure initiation. Fish were maintained in 20 psu reconstituted seawater (RSW, Crystal Sea ${ }^{\circledR}$, Marine Enterprises International, Essex, MD) at $23^{\circ} \mathrm{C}$ throughout culturing and experimental procedures. Sheepshead minnows are abundant in estuaries along the southeastern and eastern coast of the United States and are widely used in routine toxicity testing of whole effluent and receiving waters (ASTM, 1999) as well as in ecotoxicological research (e.g., Manning et al., 1999; Klerks and Moreau, 2001; Lytle et al., 2003; Jonsson et al., 2004).

Adult FB were collected from an oyster hatchery on the bay side of Grand Isle (Louisiana) on two occasions in August and September of 2003. Sources of contamination by energetic compounds are unknown for that area. Bags of oysters held in shallow water were lifted onto a net and the FB that fell from the bags were collected. FB were maintained in the laboratory in 20-gallon aquaria containing 25 psu RSW at $25^{\circ} \mathrm{C}$. The fish were fed daily with Hikari ${ }^{\mathbb{B}}$ (Hayward, CA) tropical marine fish food. Oyster shells were added to the aquaria to provide shelter. The FB are common in tropical and sub-tropical marine nearshore environments. They typically inhabit the space among oyster shells associated with reefs and typically measure $4 \mathrm{~cm}$ in length as adults (Crabtree and Middaugh, 1982). They seek structure when added to an aquarium and tend to be sedentary, frequently staying in one location for extended times. When added to a beaker with sediment and oyster shell, they swim under the shell and maintain extended contact with the sediment.

Experimental fish used in this study were treated humanely, and their use did not violate regulations per the Department of Defense document, "The Care and Use of Laboratory Animals in DOD Programs" (SECNAVINST 3900.38C).

\subsection{Chemicals}

Non-labeled trinitrotoluene (TNT) was purchased from Sigma Chemical (St. Louis, MO). $\left[{ }^{14} \mathrm{C}\right]$ labeled TNT( $\left.\left[{ }^{14} \mathrm{C}\right] \mathrm{TNT}, 40 \mathrm{Ci} \mathrm{mol}^{-1}\right)$ was purchased from Chem Service (Westchester, PA). Manufacturer reported radiochemical and chemical purities were $>98$ percent for all compounds.

\subsection{Sediment}

Sandy sediment was collected from a pristine site in Grand Isle, LA and finegrained sediment was collected from a pristine site in the vicinities of the Louisiana Universities Marine Consortium in Cocodrie, LA. Both sites are distant from known anthropogenic sources of contamination. The two sediments were mixed to create sediment with the appropriate texture for laboratory spiking and use in fish exposure experiments. The total organic carbon content of the sediment was $1.1 \%$.

2.4. Sheepshead minnow toxicity and bioaccumulation experiment: effect of direct contact with sediment

Sediment was spiked with $\left[{ }^{14} \mathrm{C}\right] \mathrm{TNT}$ prepared with non-radiolabeled TNT to result in a $\left[{ }^{14} \mathrm{C}\right] \mathrm{TNT}$ constant dosing concentration in each of the $5 \mathrm{~mL}$ dosing solutions prepared for each sediment treatment. Solutions consisted of a constant amount of $\left[{ }^{14} \mathrm{C}\right]$ TNT targeting a concentration of $5 \times 10^{4} \mathrm{dpm} \mathrm{g}^{-1}$ sediment dry weight and the appropriate amount of non-radiolabeled TNT dissolved in acetone targeting the concentrations of $330 \mu \mathrm{mol} \mathrm{kg}^{-1}$ dry wt $\left(75 \mathrm{mg} \mathrm{kg}^{-1}\right.$ ) (Low treatment) and $6200 \mu \mathrm{mol} \mathrm{kg}^{-1}$ dry wt (1409 $\mathrm{mg} \mathrm{kg}^{-1}$ ) (High treatment). The specific activity $\left(\mathrm{dpm} \mu \mathrm{mol}^{-1}\right)$ of the isotopically diluted $\left[{ }^{14} \mathrm{C}\right] \mathrm{TNT}$ of each spiking solution was determined by measuring radioactivity $\left(\mathrm{dpm} \mathrm{mL}^{-1}\right)$ via liquid scintillation counting (LSC) and TNT concentration ( $\mu \mathrm{mol} \mathrm{mL} \mathrm{m}^{-1}$ ) via high-performance liquid chromatography (HPLC) analysis of acetonitrile extracts. Radioactivity measured in the exposure media (sediment and overlying water) and in tissues was expressed as molar equivalents of TNT $\left(\mu \mathrm{mol} \mathrm{kg}{ }^{-1}\right)$ by dividing the measured radioactivity by the specific activity derived from the appropriate dosing solution. Dosing solutions were added to sediment via clean quartz sand. Each dosing solution was added to $30 \mathrm{~g}$ of dry sand contained in an aluminum weigh boat under a fume hood. After evaporation of the solvent (approximately $30 \mathrm{~min}$ ), TNTcoated sand was added to a 4 - $\mathrm{L}$ beaker containing $2.5 \mathrm{~kg}$ of sediment. Sediment and sand were then vigorously mixed for $4 \mathrm{~h}$ with a laboratory impeller mixer (Lightnin, Avon, NY). Spiked sediments were stored at $4{ }^{\circ} \mathrm{C}$ in the dark for a total of 24 days before use in the experiment. The sediment was used in the exposures after 24 days in storage for consistency purposes with unlabeled TNT experiments (as described in Section 2.5, upon verifying relatively steady concentrations of TNT and its major transformation products in the sediments). Sediments were sampled for radioactivity and concentration of TNT and its major transformation products immediately before use in the experiment.

Approximately $200 \mathrm{~g}$ of spiked sediments (Low and High and control treatments) were added to 1-L beakers, with eight replicates per treatment. Approximately $600 \mathrm{~mL}$ of 20 psu RSW was then added with minimal disturbance. Four beakers per treatment received a piece of $1-\mathrm{mm}$ pore size Nitex mesh that created a barrier midway in the water column to prevent fish from having direct contact with the sediment surface. The disk-shape Nitex mesh with a diameter slightly higher than the inner diameter of the beaker was kept in place by its natural pressure against the beaker inner wall. Each sediment treatment yielded two secondary treatments, screened (S) and non-screened (NS).

Each experimental beaker received 10 fish weighing 30-50 mg each. Beakers were maintained in a water bath under gold fluorescent light at $23^{\circ} \mathrm{C}$. The exposure duration was 4 days and fish were not fed. Water (sampled daily) and sediment (sampled at experiment initiation and termination) were analyzed for radioactivity and concentration of TNT and its main breakdown products. At exposure termination, surviving fish from each beaker were enumerated, killed by pithing, weighed, and extracted for whole body residue determination. Tissue concentrations were measured as total TNT-molar-equivalents, determined using radioactivity, and molar amounts of HPLC-quantifiable compounds. This experiment was conducted at the US Army Engineer Research and Development Center (Vicksburg, MS).

\subsection{Freckled blenny toxicity and bioaccumulation experiment}

Sediments were spiked with TNT (Chem Service, West Chester, PA, >98\% purity) targeting dry weight concentrations of $0 \mu \mathrm{mol} \mathrm{kg}{ }^{-1}$ (control), $130 \mu \mathrm{mol}$ $\mathrm{kg}^{-1}$ (30 mg kg${ }^{-1}$ ) (Low treatment), $440 \mu \mathrm{mol} \mathrm{kg}^{-1}$ (100 $\mathrm{mg} \mathrm{kg}^{-1}$ ) (Medium treatment) and $1320 \mu \mathrm{mol} \mathrm{kg}^{-1}\left(300 \mathrm{mg} \mathrm{kg}^{-1}\right.$ ) (High treatment) on a dry-weight basis. TNT was delivered to the sediment via coated quartz sand followed by $4 \mathrm{~h}$ of vigorous mixing. Spiked sediments were stored at $4{ }^{\circ} \mathrm{C}$ and sampled after $8,13,19$ and 24 days for chemical analysis. The sediment was used in the exposures after 24 days in storage upon verifying relatively steady concentrations of TNT and its major transformation products in the sediments (Fig. 1).

Two sediment exposures using different batches of field-collected fish were conducted, one lasting 1 day and the second, 7 days. The second exposure was performed within a week from the initiation of the first experiment.

Spiked sediments ( $200 \mathrm{~g}$ ) followed by $25 \mathrm{psu}$ RSW $(600 \mathrm{~mL})$ were added to $1-\mathrm{L}$ beakers with minimal disturbance of the sediment. One fish was added to each beaker. Four replicates were used in the 1-day exposure and seven replicates were used in the 7-day exposure for each treatment. Beakers were maintained in an environmental chamber in the dark at $23^{\circ} \mathrm{C}$ to prevent photodegration of TNT. Fish in the 7-day exposure were fed frozen brine shrimp daily. Each beaker received trickle aeration. The overlying water was not exchanged during the exposures. At exposure termination, overlying water and surviving fish were sampled from each beaker, killed by pithing, and stored for chemical analysis at 4 and $-20^{\circ} \mathrm{C}$, respectively. This experiment was conducted at Louisiana State University (Baton Rouge, LA).

\subsection{Freckled blenny feeding experiment}

Exposure units were $350 \mathrm{~mL}(150 \times 75 \mathrm{~mm})$ crystallizing dishes containing $200 \mathrm{~mL}$ of sediment suspended in 25 psu RSW (2000 g dry sediment $\mathrm{L}^{-1}$ ). Each dish received one fish weighing $0.5-3.0 \mathrm{~g}$. Ten replicates were used for each treatment. Fish were exposed to suspended sediment for $24 \mathrm{~h}$ before prey were added to the dishes. Two of the treatments used in the FB toxicity and bioaccumulation experiment (control and high TNT treatment (target spiked concentrations of 0 and $1320 \mu \mathrm{mol} \mathrm{kg}{ }^{-1}$ dry wt)) were used for the feeding experiment. Twenty live adult amphipods, Hyalella azteca, acclimated to 25 psu seawater, were added to the feeding arena as prey organisms. Fish were allowed to feed for one hour, after which they were removed from the dish. The whole contents of the dish were sieved and the remaining amphipods representing those not preyed upon by the fish were removed and enumerated. 


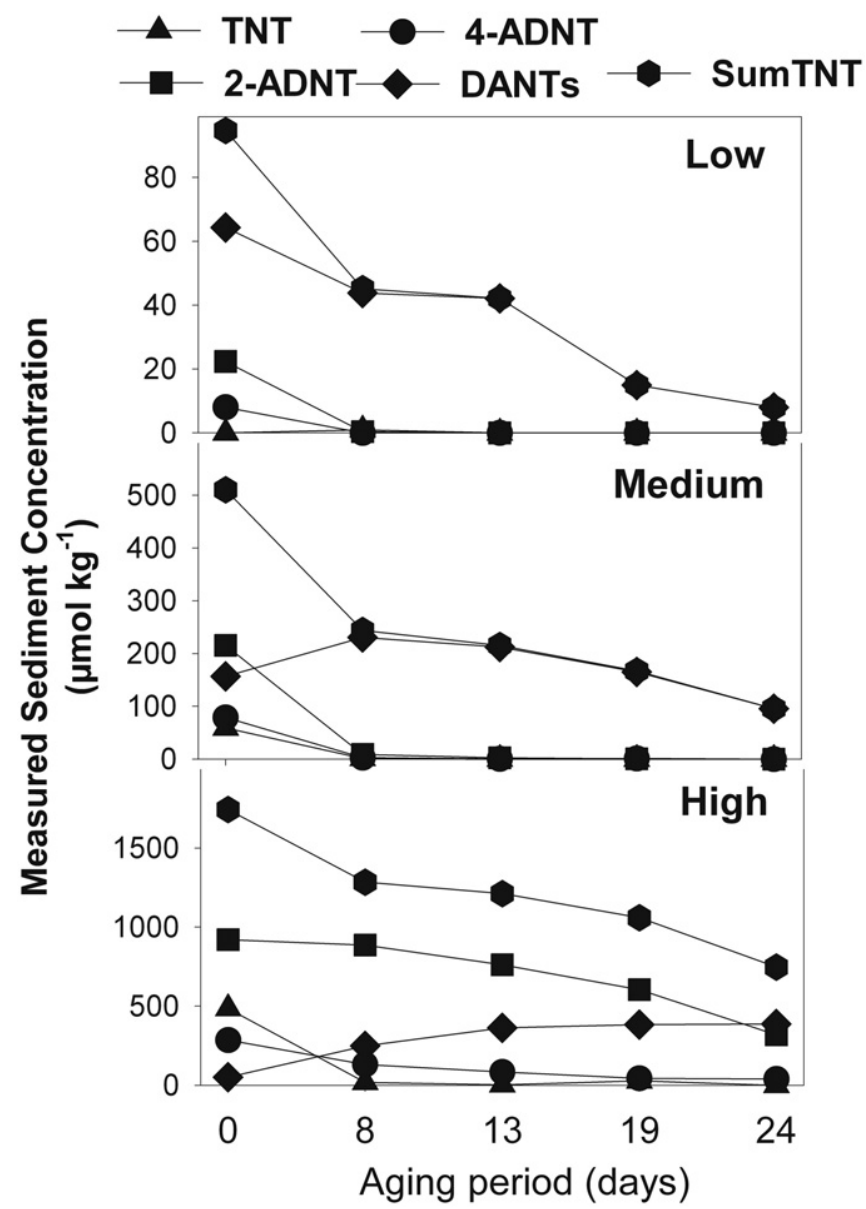

Fig. 1. Freckled blenny sediment experiment. Concentration of TNT, 4-ADNT, 2ADNT, DANTs, and the sum concentration of TNT and its transformation products (Sum HPLC) in spiked sediments during the 24-day storage period prior to exposure experiments.

\subsection{Chemical analysis}

\subsubsection{Sediment extraction}

Sediment samples were not air-dried before extraction, as recommended by Nipper et al. (2004) for related compounds, to minimize potential degradation to unknown and solvent-resistant degradation products. For each sediment sample, three subsamples $(0.05-0.1 \mathrm{~g})$ were assayed for radioactivity as described below and one sample $(5 \mathrm{~g})$ was vigorously mixed with $10 \mathrm{~mL}$ of acetonitrile and sonicated for $18 \mathrm{~h}$ (Branson 3200, Branson Ultrasonics, Danbury, CT) in an $18^{\circ} \mathrm{C}$ water bath (Neslab RTE-111, Neslab Instruments, Newington, NY). The extract was recovered, filtered through polytetrafluoroethylene (PTFE) syringe filters (Nalge Nunc, Rochester, NY), and mixed with ultrapure water on a 1:1 ratio by volume. Analytes in the extract were quantified as described below. Sediment moisture content was determined in triplicate samples by the weight ratio of wet and ovendried sediment overnight at $55^{\circ} \mathrm{C}$.

\subsubsection{Overlying water samples}

Overlying water was sampled directly from the exposure beaker. Conventional analysis of water was performed as described in Section 2.7.5 and water samples were assayed for radioactivity as described in Section 2.7.5.

\subsubsection{Tissue extraction}

The JSHM were transferred to polypropylene bead-beater vials. Each via received $100 \mathrm{mg}$ of 1 -mm glass beads and $0.75 \mathrm{~mL}$ of HPLC grade acetonitrile. Samples were homogenized using a mini bead-beater (Biospec, Barttlesville, OK) for $100 \mathrm{~s}$ at 4200 oscillations $\mathrm{min}^{-1}$ and placed on ice. The sonicated samples were then centrifuged for $10 \mathrm{~min}$ at $4{ }^{\circ} \mathrm{C}$. A $0.05 \mathrm{~mL}$ sample of the supernatant was quantified for radioactivity as described below. A $0.5 \mathrm{~mL}$ sample of the supernatant received $0.5 \mathrm{~mL}$ of $1 \% \mathrm{CaCl}_{2}$ and was sonicated for $1 \mathrm{~h}$ in an $18{ }^{\circ} \mathrm{C}$ water bath. The sonicated samples were filtered through $0.45 \mu \mathrm{m}$ PTFE syringe filters into amber sample vials and analyzed as described below. FB stored frozen were thawed and sliced into pieces using a scalpel and homogenized in $5 \mathrm{~mL}$ of acetonitrile using a
Brinkman Polytron PT3000 (Brinkman Instruments, Westbury, NY) homogenizer. Fish homogenates were centrifuged $(250 \mathrm{~g})$ for $15 \mathrm{~min}$ at $4{ }^{\circ} \mathrm{C}$ and $1 \mathrm{~mL}$ of the supernatant received $1 \mathrm{~mL}$ of $1 \% \mathrm{CaCl}_{2}$ and were sonicated for $1 \mathrm{~h}$ in an $18{ }^{\circ} \mathrm{C}$ water bath. The sonicated samples were filtered through $0.45 \mu \mathrm{m}$ PTFE syringe filters into amber sample vials. Analytes were quantified as described below.

2.7.4. Analytical chemistry

The compounds TNT, 2-ADNT, 4-ADNT, DANTs (concurrent detection of 2 , 4-DANT and 2,6-DANT isomers) in aqueous samples and solvent extracts were separated and quantified by high-performance liquid chromatography (HPLC) following a modification of US Environmental Protection Agency SW-486 Method 8330. Analyses were conducted with an Agilent 1100 Series HPLC (Palo Alto, CA) equipped with a Supelco RP-Amide C-16 column and a diode array detector Sample injection volume was $100 \mu \mathrm{l}$ with a flow rate of $1 \mathrm{~mL} / \mathrm{min}$ and column temperature of $45^{\circ} \mathrm{C}$. An isocratic mobile phase consisting of $55 \%$ methanol and $45 \%$ water was utilized. Absorbance intensities were measured at 230 and $254 \mathrm{nM}$. Peak identification was based on retention time with spectral analysis confirmation. The laboratory reporting limit for all analytes was $3 \mu \mathrm{mol} \mathrm{kg}^{-1}$ dry wt $\left(\sim 0.6 \mathrm{mg} \mathrm{kg}^{-1}\right)$ for sediment samples, $0.5 \mu \mathrm{mol} \mathrm{L}^{-1}\left(\sim 0.1 \mathrm{mg} \mathrm{L}^{-1}\right)$ for water samples, and $5 \mu \mathrm{mol} \mathrm{kg}^{-1}$ wet wt $\left(\sim 1 \mathrm{mg} \mathrm{kg}^{-1}\right)$ for tissue samples. Recoveries of TNT ranged from 90 to $98 \%$.

\subsubsection{Radioactivity assay}

Aqueous samples were placed in a xylene-based scintillation cocktail (3a70b, Research Product International, Mt. Prospect, IL) and assayed for radioactivity on a Tri-Carb liquid scintillation analyzer (Model 2500 TR, Packard Instrument, Meridien, CT). Sediment (approximately $50 \mathrm{mg}$ ) was disrupted in a scintillation cocktail using a Branson Sonifier 450 high-intensity probe-sonicator (Danbury, CT) and stored for $24 \mathrm{~h}$ before radioactivity analysis.

\subsubsection{Presentation of analytical data}

The LSC- and HPLC-quantified chemical analyses data were used to determine concentrations expressed as:

- Single-compound concentrations: represent the molar concentration of compounds that were identified and quantified using HPLC.

- Quantified compounds sum concentration: represent the molar concentration of compounds that were identified and quantified using HPLC. Referred to as Sum HPLC.

- Total molar-equivalents sum concentration: represent the sum-molar concentration of TNT and all transformation products quantified using LSC and specific activity of radiolabeled TNT. Referred to as Sum LSC.

\section{Results}

\subsection{Sheepshead minnow toxicity and bioaccumulation experiment: effect of sediment contact}

The initial Sum LSC sediment concentrations were substantially (3-10 times) higher than Sum HPLC sediment concentrations for both treatments and indicated the presence of extraction-resistant non-identified transformation products in the sediment (Table 1). For the Low treatment sediment, DANTs were the dominant HPLC-identified compounds at exposure initiation and the only HPLC-identified compounds at exposure termination (Table 1). The compounds TNT, 2-ADNT, 4-ADNT and DANTs were detected in sediment solvent extracts for the High treatment (Table 1 ) at exposure initiation and termination again using HPLC-identified compounds.

The mean Sum LSC concentrations in the overlying water increased during the exposure period (Fig. 2) for both Low and High treatments, but were substantially higher (approximately 40 times) in the High treatment at experiment termination. Only DANTs were detected in the overlying water of the Low treatment beakers while TNT, 2-ADNT, 4-ADNT and DANTs were detected in the High treatment (Fig. 2). The Sum LSC concentration was only slightly higher than the Sum HPLC concentration for the High treatment, indicating that non-identified compounds made up only a small fraction of the total concentrations in overlying water (Fig. 2 and Table 2). For the Low treatment, however, the 
Table 1

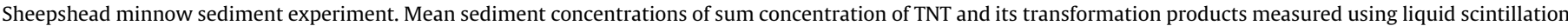

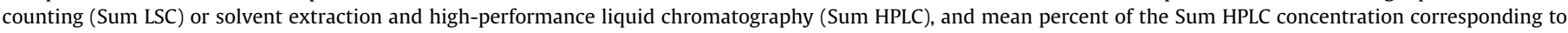
TNT, 4-ADNT, 2-ADNT and DANTs. S=screened, NS=non-screened. Numbers in parentheses correspond to a value of 1 standard deviation.

\begin{tabular}{|c|c|c|c|c|c|c|c|c|}
\hline \multirow[t]{3}{*}{ Treatment } & \multirow[t]{3}{*}{ Sampling period } & \multicolumn{3}{|c|}{ Sediment concentration $^{\mathrm{a}}$} & \multicolumn{4}{|c|}{ Percent of total } \\
\hline & & \multirow{2}{*}{$\frac{\text { Sum LSC }}{\left(\mu \mathrm{mol} \mathrm{kg}{ }^{-1}\right)}$} & \multicolumn{2}{|l|}{ Sum HPLC } & \multirow[b]{2}{*}{ TNT } & \multirow[b]{2}{*}{ 4-ADNT } & \multirow[b]{2}{*}{ 2-ADNT } & \multirow[b]{2}{*}{ DANTs } \\
\hline & & & $\left(\mu \mathrm{mol} \mathrm{kg}{ }^{-1}\right)$ & $\left(\mathrm{mg} \mathrm{kg}^{-1}\right)$ & & & & \\
\hline Low & Initial & $333.4(25.8)$ & $40.3(5.2)$ & $6.9(0.9)$ & $2.5(0.2)$ & $4.7(0.1)$ & 0 & $87.9(0.2)$ \\
\hline Low-S & Final & $282.8(18.6)$ & $27.4(0.9)$ & $4.6(0.1)$ & 0 & 0 & 0 & 100 \\
\hline Low-NS & Final & $276.7(10.8)$ & $26.7(1.2)$ & $4.5(0.2)$ & 0 & 0 & 0 & 100 \\
\hline High & Initial & $6176.0(848.6)$ & $1702.3(46.7)$ & $348.4(11.3)$ & $36.9(3.0)$ & $9.6(0.4)$ & $42.2(1.9)$ & $11.3(0.8)$ \\
\hline High $-\mathrm{S}$ & Final & $2811.8(557.1)$ & $1057.2(19.4)$ & $210.0(3.9)$ & $26.7(0.3)$ & $13.8(0.1)$ & $38.0(0.2)$ & $21.4(0.2)$ \\
\hline High-NS & Final & 2859.4 (331.9) & $1076.1(12.3)$ & $213.7(2.2)$ & $26.2(0.5)$ & $14.3(0.1)$ & $38.7(0.1)$ & $20.9(0.4)$ \\
\hline
\end{tabular}

${ }^{\text {a }}$ Expressed on dry-weight basis.

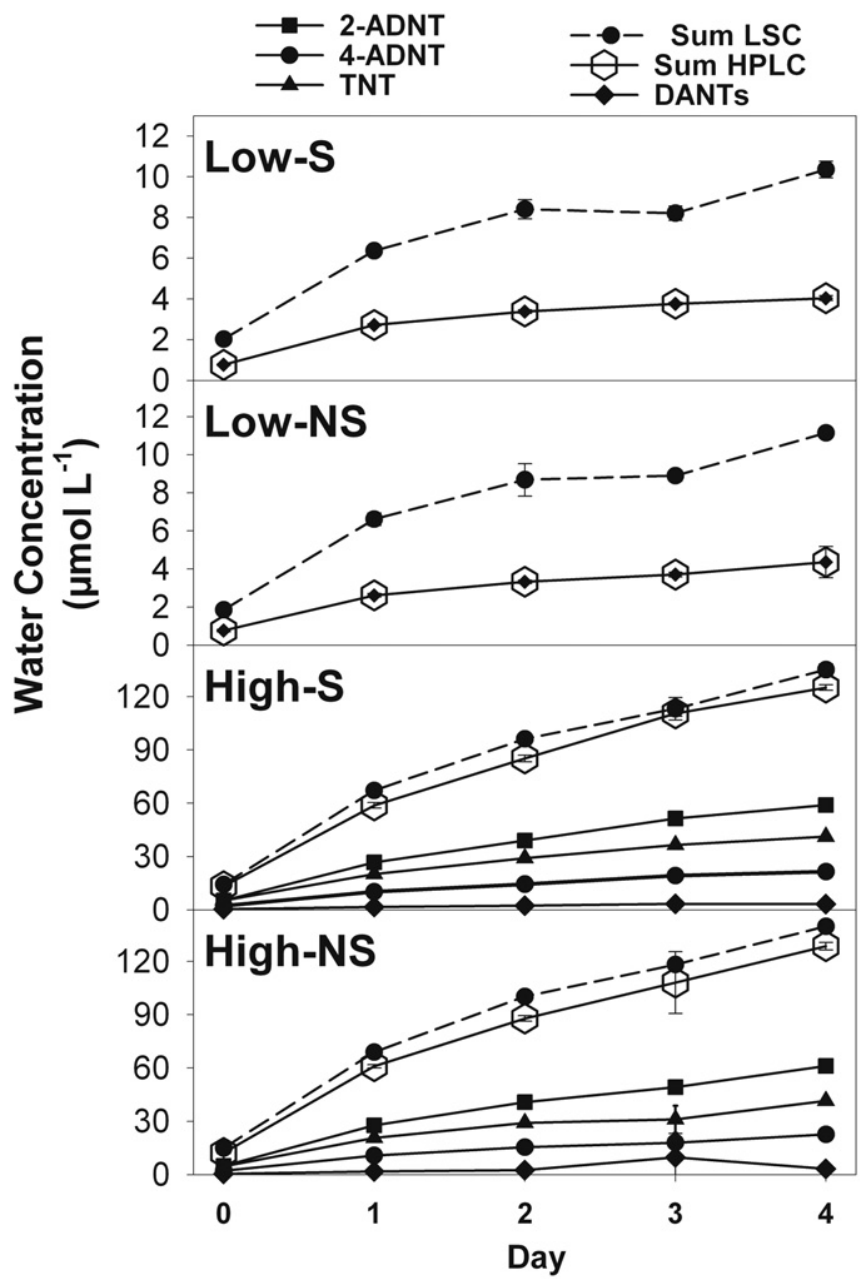

Fig. 2. Sheepshead minnow sediment experiment. Concentration of TNT, 4-ADNT, 2-ADNT and DANTs and the sum concentration of TNT and its transformation products as measured using liquid scintillation counting (Sum LSC) or highperformance liquid chromatography (Sum HPLC) in the overlying water during 4day exposure. $\mathrm{S}=$ screened, $\mathrm{NS}=$ non-screened.

difference between Sum LSC and Sum HPLC concentrations indicates that most of the TNT transformation products in the water were non-identified compounds (Fig. 2 and Table 2).

The presence of the screen separating the fish from the sediment did not significantly affect the Sum LSC and Sum HPLC concentrations in the water or sediment at termination of the experiment as indicated by pairwise comparisons between screened and nonscreened treatment replicate data (Student's $t$-test, $p<0.05$ ).

The total amount of Sum HPLC associated with the sediment phase (including pore water) and overlying water was determined at experiment termination using water and sediment Sum HPLC concentration data and their approximate mass in the beaker. Most of the compounds in the beaker were associated with the sediment, with approximately one-third of the total mass in the beaker residing in the overlying water in beakers without screen and with the screen.

Mean survival was high $(\geq 90 \%)$ in the control and in the Low treatment with the screen and without the screen. Fish surviving the 4-day exposures were used for chemical analysis of tissues. All JSHM died within the first $24 \mathrm{~h}$ of exposure in the High treatment. Those dead fish were analyzed for body residue. Body residues (Table 3 ) in fish from the screened treatments were significantly higher than in fish from the non-screened treatment in the Low treatment (Student's $t$-test, $p<0.05$ ) but not statistically different from fish from non-screened treatments in the High treatment $(p=0.182)$. Body residues determined using HPLC were below method detection limit in fish from the Low treatment. Only ADNTs were detected in fish sampled from the High treatment (Table 3 ).

The bioconcentration factor (BCF) is the ratio of the concentration of chemicals in an aquatic organism to the concentration in the surrounding water and is the most frequently used indicator of a compound's propensity to bioaccumulate in aquatic organisms. Although BCFs are typically determined for single compounds, BCF values are reported here for Sum LSC, and Sum HPLC tissue and water concentrations (Table 4). For the High treatment, values were determined using day 1 data because of full fish mortality during the first day of exposure. For the Low treatment, day 4 body residue and water chemistry data were used. The BCF values were not statistically different between fish from non-screened and screened treatments in both Low and High treatments using Sum LSC values and for the High treatment using HPLC-measured values or between fish from Low and High treatments in both nonscreened and screened treatments (Student's $t$-test, $p>0.1$ ).

\subsection{Freckled blenny toxicity and bioaccumulation experiments}

Spiked TNT degraded rapidly to aminated breakdown products during storage (Fig. 1). The concentration of SumTNT decreased sharply in the Low and Medium treatments and moderately in the High treatment. Transformation processes apparently occurred at a much slower rate after 8 days of storage in the Medium and High treatments. At termination of the 24-day storage period, Sum HPLC measured concentrations were lower than the target 
Table 2

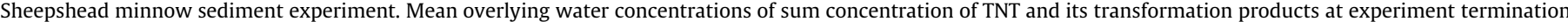

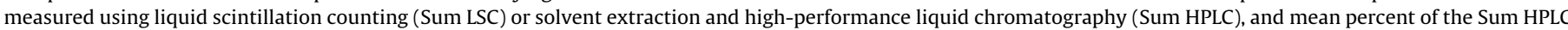

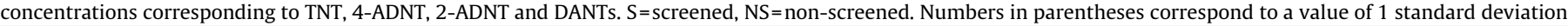

\begin{tabular}{|c|c|c|c|c|c|c|}
\hline \multirow[t]{2}{*}{ Treatment } & \multirow[t]{2}{*}{ Sum LSC $\left(\mu \mathrm{mol} \mathrm{L}{ }^{-1}\right)$} & \multirow[t]{2}{*}{ Sum HPLC $\left(\mu \mathrm{mol} \mathrm{L}^{-1}\right)$} & \multicolumn{4}{|c|}{ Percent of total } \\
\hline & & & TNT & 4-ADNT & 2-ADNT & DANTs \\
\hline Low $-\mathrm{S}$ & $10.4(0.4)$ & $4.0(0.1)$ & 0 & 0 & 0 & 100 \\
\hline Low-NS & $11.1(0.1)$ & $4.4(0.8)$ & 0 & 0 & 0 & 100 \\
\hline High $-S$ & $135.2(3.3)$ & $125.2(1.5)$ & $33.0(0.4)$ & $17.2(0.1)$ & $47.2(0.3)$ & $2.7(0.0)$ \\
\hline High-NS & $139.7(2.0)$ & $128.6(2.1)$ & $32.3(0.5)$ & $17.6(0.2)$ & $47.5(0.3)$ & $2.6(0.1)$ \\
\hline
\end{tabular}

Table 3

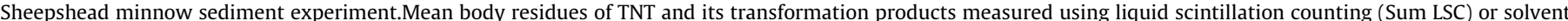

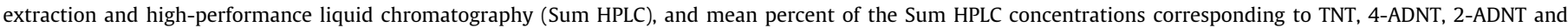

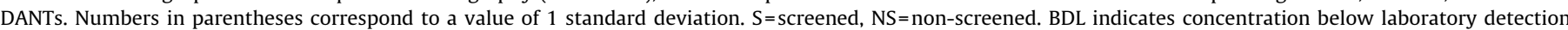
limit. ND indicates not determined because of insufficient mortality or data.

\begin{tabular}{|c|c|c|c|c|c|c|}
\hline \multirow{2}{*}{ Treatment } & \multirow{2}{*}{ Sum $\operatorname{LSC}^{\mathrm{a}}\left(\mu \mathrm{mol} \mathrm{kg}{ }^{-1}\right)$} & \multirow{2}{*}{ Sum HPLC $\left(\mu \mathrm{mol} \mathrm{kg}{ }^{-1}\right)$} & \multicolumn{4}{|c|}{ Percent of total } \\
\hline & & & TNT & 4-ADNT & 2-ADNT & DANTs \\
\hline Low-S & $95.7(16.4)$ & BDL & ND & ND & ND & ND \\
\hline Low-NS & $70.4(10.4)$ & $\mathrm{BDL}$ & ND & ND & ND & ND \\
\hline High $-S$ & $524.6(55.1)$ & 309.8 (48.6) & 0 & $39.0(0.5)$ & $61.0(0.5)$ & 0 \\
\hline High-NS & $587.6(62.8)$ & $292.7(125.8)$ & 0 & $38.8(0.6)$ & $61.3(0.6)$ & 0 \\
\hline
\end{tabular}

a Expressed on wet-weight basis.

Table 4

Sheepshead minnow sediment experiment.Mean bioconcentration factor (BCF) values for the sum concentration of TNT and its transformation products as measured using liquid scintillation counting (Sum LSC) or solvent extraction and high performance liquid chromatography (Sum HPLC). S=screened, NS=nonscreened. Numbers in parentheses correspond to a value of 1 standard deviation. ND indicates not determined because of lack of body residue data.

\begin{tabular}{lll}
\hline Treatment & \multicolumn{1}{l}{ BCF } \\
\cline { 2 - 3 } & Sum LSC $\left(\mathrm{L} \mathrm{kg}^{-1}\right)$ & Sum HPLC $\left(\mathrm{L} \mathrm{kg}^{-1}\right)$ \\
\hline Low-S & $8.6(2.2)$ & ND \\
Low-NS & $6.3(0.9)$ & ND \\
High—S & $3.9(0.3)$ & $5.3(0.7)$ \\
High-NS & $4.2(0.5)$ & $4.8(2.1)$ \\
\hline
\end{tabular}

concentrations and DANTs were the sole compounds detected in the Low and Medium treatments and 2-ADNT was the dominating compound in the High treatment (Table 5).

Measured Sum HPLC concentrations in the sediment at termination of the 1- and 7-day exposures were lower than target concentrations, with the ratio of measured-to-target concentrations decreasing with increasing spiking concentration; the transformation product DANTs were the only detectable compounds in the Low and Medium treatments, whereas both DANTs and ADNTs were present in similar concentrations in the High treatment for both exposures (Table 6). Four replicates per treatment were assessed at termination of the 1- and the 7-day exposures.

The Sum HPLC concentration in the overlying water at exposure termination was below detection limit in the Low treatment and was higher in the 7-day exposure for the two other treatments (Table 7), but the difference was significantly different only for the Medium treatment. DANTs were the only transformation products detected in the Medium treatment in both exposures and in the High treatment in the 7-day exposure, whereas both DANTs and ADNTs were present in the High treatment in the 1-day exposure (Table 7). At termination of the 1- and 7-day experiments, approximately $20 \%$ of the total amount of Sum HPLC in the beakers was in the overlying water in the Medium and High treatments.
The sum amount of ADNTs and DANTs associated with the sediment phase (including pore water) and overlying water was determined at experiment termination using water and sediment concentration data and their approximate mass in the beaker. Most of the compounds in the beaker were associated with the sediment, with approximately one-fifth of the total mass in the beaker residing in the overlying water for the Medium and High treatments, and but no detectable fraction present in the water of the Low treatment beakers.

No fish mortality occurred in the 1-day exposure. In the 7-day exposure, mortality of the single fish present in each replicate (three in the control and two in each TNT treatment) occurred in beakers where aeration failed overnight at day 2 . Therefore, mortality was likely caused by oxygen depletion rather than to the presence of TNT and its transformation products in the sediment.

Four whole-fish replicates per treatment were assessed for body residues at termination of the 1- and the 7-day exposures. Detectable concentrations of TNT transformation products were present in tissues only of fish exposed to the High treatment (Table 8). The dominating compound in the tissues was 2-ADNT for the 1-day exposure whereas DANTs were the dominant compounds for the 7-day exposure. Water and tissue Sum HPLC concentrations at exposure termination were used for determining BCFs values (Table 8).

\subsection{Freckled blenny feeding experiment}

The number of amphipods ingested by FB was significantly lower (Students $t$-test, $p<0.05$ ) in the TNT-contaminated treatment $(6.7 \pm 1.9$, mean \pm 1 standard deviation $)$ than in the control $(12.4 \pm 3.2)$ during the 1 -h exposure to suspended sediment.

\section{Discussion}

\subsection{Fate of TNT}

TNT spiked to sediments degraded rapidly to aminated breakdown products during storage in both experiments. Extensive 
Table 5

Freckled blenny sediment experiment. Sum concentrations of TNT and its transformation products in sediments at termination of 24-day storage period.

\begin{tabular}{|c|c|c|c|c|c|c|c|}
\hline \multirow[t]{2}{*}{ Sediment treatment } & \multirow{2}{*}{$\begin{array}{l}\text { Target }^{\mathrm{a}} \text { concentration } \\
\left(\mu \mathrm{mol} \mathrm{kg}{ }^{-1}\right)\end{array}$} & \multicolumn{2}{|c|}{ Measured $^{\mathrm{a}}$ sum concentration } & \multicolumn{4}{|c|}{ Percent of total } \\
\hline & & $\left(\mu \mathrm{mol} \mathrm{kg}{ }^{-1}\right)$ & $\left(\mathrm{mg} \mathrm{kg}^{-1}\right)$ & TNT & 4-ADNT & 2-ADNT & DANTs \\
\hline Low & 130 & 15 & 2.5 & 0.0 & 0.0 & 0.0 & 100.0 \\
\hline Medium & 440 & 168 & 28.0 & 0.0 & 0.0 & 0.0 & 100.0 \\
\hline High & 1320 & 1186 & 198.1 & 3.2 & 4.3 & 60.1 & 32.4 \\
\hline
\end{tabular}

${ }^{a}$ Expressed on dry-weight basis.

Table 6

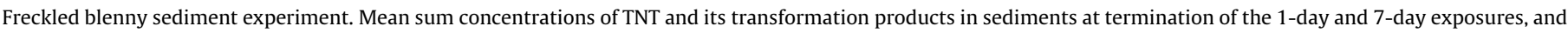

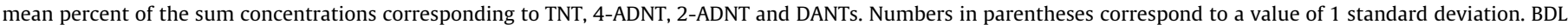
indicates concentration below laboratory detection limit.

\begin{tabular}{|c|c|c|c|c|c|c|c|}
\hline \multirow[t]{2}{*}{ Experiment } & \multirow[t]{2}{*}{ Sediment treatment } & \multicolumn{2}{|c|}{ Measured concentration ${ }^{\mathrm{a}}$} & \multicolumn{4}{|c|}{ Percent of total } \\
\hline & & $\left(\mu \mathrm{mol} \mathrm{kg}{ }^{-1}\right)$ & $\left(\mathrm{mg} \mathrm{kg}^{-1}\right)$ & TNT & 4-ADNT & 2-ADNT & DANTs \\
\hline \multirow[t]{3}{*}{1 day } & Low & $8(1)$ & $1.3(0.2)$ & 0 & 0 & 0 & 100 \\
\hline & Medium & $108(26)$ & $16(4.2)$ & 0 & 0 & 0 & 100 \\
\hline & High & $850(163)$ & $135.5(13.6)$ & 0 & 5.3 & 42.4 & 52.3 \\
\hline \multirow[t]{3}{*}{7 days } & Low & BDL & $\mathrm{BDL}$ & ND & ND & ND & ND \\
\hline & Medium & $75(12)$ & $12.6(2.0)$ & 0 & 0 & 0 & 100 \\
\hline & High & $648(158)$ & $118.9(30.0)$ & 0 & 0 & 54.7 & 45.3 \\
\hline
\end{tabular}

${ }^{a}$ Expressed on dry-weight basis.

Table 7

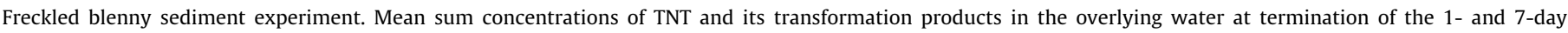

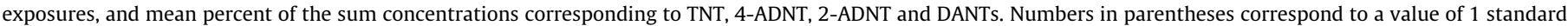
deviation. BDL indicates concentration below laboratory detection limit

\begin{tabular}{|c|c|c|c|c|c|c|c|}
\hline \multirow[t]{2}{*}{ Experiment } & \multirow[t]{2}{*}{ Sediment treatment } & \multicolumn{2}{|c|}{ Water concentration } & \multicolumn{4}{|c|}{ Percent of total } \\
\hline & & $(\mu \mathrm{mol} \mathrm{L}-1)$ & $\left(\mathrm{mg} \mathrm{L}^{-1}\right)$ & TNT & 4-ADNT & 2-ADNT & DANTs \\
\hline \multirow[t]{3}{*}{1 day } & Low & $\mathrm{BDL}$ & $\mathrm{BDL}$ & & & & \\
\hline & Medium & $4.9(0.4)$ & $0.8(0.1)$ & 0 & 0 & 0 & 100 \\
\hline & High & $41.9(4.9)$ & $7.4(0.9)$ & 0 & 2.4 & 31.7 & 65.9 \\
\hline \multirow[t]{3}{*}{7 days } & Low & $\mathrm{BDL}$ & BDL & ND & ND & ND & ND \\
\hline & Medium & $19.6(12.8)$ & $3.3(2.1)$ & 0 & 0 & 0 & 100 \\
\hline & High & $47.1(8.7)$ & $7.9(1.5)$ & 0 & 0 & 0 & 100 \\
\hline
\end{tabular}

Table 8

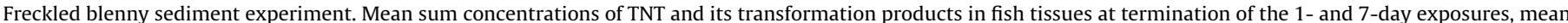

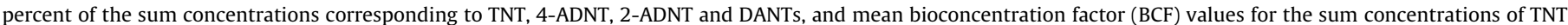

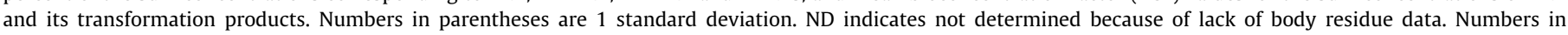
parentheses correspond to a value of 1 standard deviation. BDL indicates concentration below laboratory detection limit.

\begin{tabular}{|c|c|c|c|c|c|c|c|}
\hline \multirow[t]{2}{*}{ Experiment } & \multirow[t]{2}{*}{ Sediment treatment } & \multirow{2}{*}{$\begin{array}{l}\text { Tissue concentration }{ }^{\mathrm{a}} \\
\left(\mu \mathrm{mol} \mathrm{kg}{ }^{-1}\right)\end{array}$} & \multicolumn{4}{|c|}{ Percent of total } & \multirow[t]{2}{*}{$\mathrm{BCF}\left(\mathrm{L} \mathrm{kg}^{-1}\right)$} \\
\hline & & & TNT & 4-ADNT & 2-ADNT & DANTs & \\
\hline \multirow[t]{3}{*}{1 day } & Low & BDL & ND & ND & ND & ND & ND \\
\hline & Medium & $\mathrm{BDL}$ & ND & ND & ND & ND & ND \\
\hline & High & $175.7(132.8)$ & 0 & 6.1 & 74.4 & 19.5 & 4.2 \\
\hline \multirow[t]{3}{*}{7 days } & Low & BDL & ND & ND & ND & ND & ND \\
\hline & Medium & $\mathrm{BDL}$ & ND & ND & ND & ND & ND \\
\hline & High & $150.7(115.8)$ & 0 & 1.5 & 31.1 & 67.5 & 3.2 \\
\hline
\end{tabular}

${ }^{a}$ Expressed on dry-weight basis.

transformation of TNT to aminated transformation products occurred following spiking of sediments used in the SHM and FB experiments. Formation of aminated breakdown products was previously reported when TNT was spiked to marine or estuarine sediments (Rosen and Lotufo, 2005), freshwater sediments (Elovitz and Weber, 1999; Steevens et al., 2002; Conder et al., 2004; Lotufo and Farrar, 2005) or soils (e.g., Achtnich et al., 1999; Renoux et al.,
2000; Lachance et al., 2004). The transformation of TNT to 2-ADNT over that to 4-ADNT was favored, unlike previous observations following TNT spiking to sediments (Conder et al., 2004; Rosen and Lotufo, 2005), where transformation to 4-ADNT was favored. Reduction to 4-ADNT is thermodynamically preferable, as predicted based on the findings of McCormick et al. (1976). The reasons for the observed higher concentration of 2-ADNT than 
to 4-ADNT in the TNT-spiked sediment used in this study are unknown.

In both experiments, the Sum HPLC concentrations were lower than the target concentrations for the sediments. For sediment spiked with radiolabeled TNT used in the SHM experiment, the LSC-measured sediment concentrations were substantially higher than HPLC-measured sediment concentrations, but were similar to the target concentrations. The differences between LSC-measured and HPLC-measured concentrations and between target and HPLCmeasured concentrations indicate that a large fraction of the spiked compound was rapidly transformed to extractable compounds that were non-identifiable using HPLC (i.e, compounds other than TNT, ADNTs and DANTs) or became so strongly associated to sediment particles that they were non-solvent extractable. Highly reactive aminated transformation products of TNT, either formed due to transformation of the parent compound or directly spiked to the sediment, have been reported to form covalent bonds with organic molecules in soil or sediment particles, especially humic acids, as has been observed in soils (Achtnich et al., 1999; Thorn and Kennedy, 2002; Eriksson et al., 2004).

In both experiments, the ratio between the measured and the expected concentrations of nitroaromatic compounds increased with increasing target concentrations. A similar inverse relationship between spiking level and degree of transformation and disappearance has been previously observed for TNT and related compounds in sediments (Lotufo et al., 2001; Steevens et al., 2002; Conder et al., 2004; Lotufo and Farrar, 2005) and likely resulted from inhibition of microbial transformation as well as saturation of sites on the particles where covalent binding occurs.

Movement of TNT and related compounds from the sedimentporewater phase into the overlying water occurred during the static exposures in this study and has been reported previously (Lotufo et al., 2001; Rosen and Lotufo, 2005). Such movement of TNT has been attributed mostly to compound transfer from the porewater phase to the overlying water phase (Rosen and Lotufo, 2005). Even though JSHM in direct contact with the sediment (no-screened treatment) created enough sediment resuspension to occasionally obscure the presence of fish in the beaker, the concentration of dissolved compounds were not significantly higher than in the screened treatment where no bioturbation occurred. Increased concentration in water due to bioturbation, and consequently higher body residues, were obtained when fathead minnows were exposed to sediment ( $2 \%$ organic carbon content) spiked with benzo(a)pyrene (McCarthy et al., 2003), a substantially more hydrophobic compound. The differences in bioturbation effect between sediment-spiked SumTNT and benzo(a)pyrene in those studies are likely mostly explained by the differences in hydrophobicity, as the weakly hydrophobic TNT and its transformation products readily partition to the water column in the absence of bioturbation and the highly hydrophobic benzo(a)pyrene partions more efficiently with the greater degree of mixing of sediment and water generated by the presence of fish.

\subsection{Bioaccumulation and toxicity}

The only compounds detected in the exposure water of the Low treatment in the SHM experiment were DANTs. Those compounds, however, were not detectable in the tissues. Differences between the Sum LSC and Sum HPLC concentrations indicate that non-identified compounds were present in the water at a sum concentration exceeding that of DANTs. The presence of radioactivity in fish exposed to that treatment indicates that uptake of non-identified compounds occurred. The mean Sum LSC BCFs obtained for JSHM exposed to the Low treatment ( 6.3 and $8.6 \mathrm{~L} \mathrm{Kg}^{-1}$ ) were higher than the 2,4-DANTs BCF reported for JSHM in water exposures $\left(0.5 \mathrm{~L} \mathrm{Kg}^{-1}\right)$ (Lotufo and Lydy, 2005), revealing the higher bioaccumulative potential of those non-identified compound relative to DANTs. In the High treatment TNT, ADNTs and DANTs were present in the exposure water but only the ADNTs were detectable in whole-body extracts. Although fish were sampled less than $24 \mathrm{~h}$ from the onset of mortality, body residue data presented for that exposure should be viewed with caution since changes in body residues likely occurred between the onset of death and sampling of the fish. Such changes likely explain the lower ADNT BCFs for those fish relative to values previously reported for 2-ADNT (13.1 $\mathrm{L} \mathrm{Kg}^{-1}$ ) (Lotufo and Lydy 2005).

FB were exposed to ADNTs and DANTs via the overlying water during the 7-day exposure period. These compounds were also present in whole-body extracts of the fish exposed during the 7-day exposure period. When the BCF values determined for $\mathrm{FB}$ are compared with the Sum HPLC BCFs determined for JSHM in this study and previously in water exposures (Lotufo and Lydy, 2005), the BCF values are consistent with predicted bioaccumulation from the water.

Contact with the sediment surface and to sediment resuspended by bioturbation did not result in higher body burdens of SumTNT compared to JSHM separated from the sediment by a mesh. The bioaccumulation of TNT transformation products in FB directly exposed to sediment appeared to result solely from bioconcentration from the overlying water. These results indicate that direct contact with the sediment bed or resuspended sediment is a not relevant route of exposure to near-bottom fish.

This result for nitroaromatic compounds is in contrast with results obtained during studies of similar organic contaminants including PAHs, PCBs and other persistent organic pollutants, where it was reported that direct contact with sediment surfaces resulted in uptake by benthic fish (Stein et al., 1984; Hellou et al., 1994, 1995; Smith et al., 1996; Moermond et al., 2004; Fragoso et al., 2006). The body residue of benzo(a)pyrene via dermal contact, evaluated using anesthetized catfish (Ictalurus punctatus) placed directly on spiked sediment, was several times higher than in fish not in direct contact with the sediment (Smith et al. 1996).

Since bioaccumulation of TNT and its transformation products in fish exposed to spiked sediments in this study was likely from the water phase, previously published aqueous toxicity data are used for interpretation of the toxicity data reported here. The aqueous concentration of TNT and 2-ADNT in the water of the High treatment of the SHM experiment much exceeded the 5-day no observed effects concentration (NOEC) values for those compounds in water exposures (1.5 and $4.0 \mathrm{mg} \mathrm{L}^{-1}$, respectively) (Lotufo and Lydy, 2005). Therefore, mortality was expected at the measured water concentrations in this study. The concentrations of ADNTs and DANTs in the overlying water measured in the FB experiments were below the NOEC values for 2-ADNT and 2,4-DANT reported for JSHM in water exposures (4.0 and $56 \mathrm{mg} \mathrm{L}^{-1}$, respectively) (Lotufo and Lydy, 2005). Assuming that FB are similarly sensitive to these compounds as JSHM, contaminantrelated fish mortality in this study was not expected or observed.

Suspended sediment spiked with TNT at sublethal concentrations had strong effects on feeding behavior of FB. Sediment spiked with PAHs had a similar effect in darter goby, Gobionellus boleosoma (Gregg et al., 1997). It is likely that such reductions in feeding rate affect the fitness of blennies and other small benthic fishes (Gregg et al., 1997).

\section{Conclusions}

The aging of spiked sediments prior to exposure promoted a dramatic reduction of sediment TNT concentration. Contaminant concentrations measured using radioactivity were higher than those measured using HPLC analysis of solvent extracts, indicating the incidence of covalent binding and transformation of TNT to unidentified transformation products. Similar bioaccumulation of TNT and its transformation products by fish exposed directly to sediment and 
fish prevented from direct access to sediment provides evidence that direct contact with bed or resuspended sediment are not likely relevant routes of TNT exposure to near-bottom fish. Lethal toxicity to fish in sediment exposures was only observed when overlying water concentrations exceeded aqueous toxicity thresholds for TNT and its transformation products. Adverse effects of TNT to bottom-dwelling fish may occur when sediment acts as a source of contaminants to the overlying water. Because of extensive dilution of sediment-associated contaminants partitioning into the water column in marine environments, however, toxic concentrations are unlikely to occur near the sediment/water interface .

\section{Acknowledgments}

The US Navy Environmental Sustainability Development to Integration Program and the Environmental Quality Technology Research Program of the US Army supported this research. Permission to publish this study was granted by the Chief of Naval Operations (N456) and the Chief of Engineers. The authors thank Daniel Farrar for high-performance liquid chromatography analyses. We are grateful to Gunther Rosen, Robert George, Stanley Jacob, M. John Cullinane and Elizabeth Ferguson for their review of this manuscript.

\section{References}

Achtnich, C., Sieglen, U., Knackmuss, H.J., Lenke, H., 1999. Irreversible binding of biologically reduced 2,4,6-trinitrotoluene to soil. Environ. Toxicol. Chem. 18, 2416-2423.

American Society for Testing and Materials (ASTM)., 1999. Standard guide for conducting early life-stage toxicity tests with fishes. E 1241-98. In: Annual Book of ASTM Standards, West Conshohocken, PA, pp. 1-29.

Conder, J.M., La Point, T.W., Steevens, J.A., Lotufo, G.R., 2004. Recommendations for the assessment of TNT toxicity in sediment. Environ. Toxicol. Chem. 23, 141-149.

Crabtree, R.E., Middaugh, D.P., 1982. Oyster shell size and the selection of spawning sites by Chasmodes bosquianus, Hypleurochilus geminatus, Hypsoblennius ionthas (Pisces, Blenniidae) and Gobiosoma bosci (Pisces, Gobiidae) in 2 South Carolina estuaries. Estuaries 5, 155.

Darrach, M.R., Chutjian, A., Plett, G.A., 1998. Trace explosives signatures from World War II unexploded undersea ordnance. Environ. Sci. Technol. 32, 1354-1358.

Dave, G., 2003. Field test of ammunition (TNT) dumping in the ocean. In: Munawar, M. (Ed.), Quality Assessment and Management: Insight and Progress. Aquatic Ecosystem Health and Management Society, Washington, DC, pp. 213-220.

Ek, H., Dave, G., Nilsson, E., Sturve, J., Birgersson, G., 2006. Fate and effects of 2,4, 6 -trinitrotoluene (TNT) from dumped ammunition in a field study with fish and invertebrates. Arch. Environ. Contam. Toxicol. 51, 244-252.

Elovitz, M.S., Weber, E.J., 1999. Sediment mediated reduction of 2,4,6-trinitrotoluene and fate of the resulting aromatic (poly)amines. Environ. Sci. Technol. 33, 2617-2625.

Eriksson, J., Frankki, S., Shchukarev, A., Skyllberg, U., 2004. Binding of 2,4 6-trinitrotoluene, aniline, and nitrobenzene to dissolved and particulate soil organic matter. Environ. Sci. Technol. 38, 3074-3080.

Fragoso, N.M., Hodson, P.V., Zambon, S., 2006. Evaluation of an exposure assay to measure uptake of sediment PAH by fish. Environ. Monit. Assess. 116, 481-511.

Fuchs, J.S., Oneto, M.L., Casabe, N.B., Gomez, S.O., Tarulla, R., Vaccarezza, M. Sanchez-Rivas, C., Kesten, E.M., Wood, E.J., 2001. Ecotoxicological characterization of a disposal lagoon from a munition plant. Bull. Environ. Contam. Toxicol. 67, 696-703.

Gregg, J.C., Fleeger, J.W., Carman, K.R., 1997. Effects of suspended, dieselcontaminated sediment on feeding rate in the darter goby, Gobionellus boleosoma (Teleostei: Gobiidae). Mar. Pollut. Bull. 34, 269-275.

Hellou, J., Payne, J.F., Upshall, C., Fancey, L.L., Hamilton, C., 1994. Bioaccumulation ofaromatic hydrocarbons from sediments-a dose response study with flounder (Pseudopleuronectes americanus). Arch. Environ. Contam. Toxicol. 27, 477-485.

Hellou, J., Mackay, D., Fowler, B., 1995. Bioconcentration of polycyclic aromatic compounds from sediments to muscle of finfish. Environ. Sci. Technol. 29, 2555-2560.
Jonsson, G., Bechmann, R.K., Bamber, S.D., Baussant, T., 2004. Bioconcentration, biotransformation, and elimination of polycyclic aromatic hydrocarbons in sheepshead minnows (Cyprinodon variegatus) exposed to contaminated seawater. Environ. Toxicol. Chem. 23, 1538-1548.

Klerks, P.L., Moreau, C.J., 2001. Heritability of resistance to individual contaminants and to contaminant mixtures in the sheepshead minnow (Cyprinodon variegatus). Environ. Toxicol. Chem. 20, 1746-1751.

Lachance, B., Renoux, A.Y., Sarrazin, M., Hawari, J., Sunahara, G.I., 2004. Toxicity and bioaccumulation of reduced TNT metabolites in the earthworm Eisenia andrei exposed to amended forest soil. Chemosphere 55, 1339-1348.

Lotufo, G.R., Farrar, J.D., Inouye, L.S., Bridges, T.S., Ringelberg, D.B., 2001. Toxicity of sediment-associated nitroaromatic and cyclonitramine compounds to benthic invertebrates. Environ. Toxicol. Chem. 20, 1762-1771.

Lotufo, G.R., Farrar, J.D., 2005. Comparative and mixture sediment toxicity of trinitrotoluene and its major transformation products to a freshwater midge. Arch. Environ. Contam. Toxicol. 49, 333-342.

Lotufo, G.R., Lydy, M.J., 2005. Comparative toxicokinetics of explosive compounds in sheepshead minnows. Arch. Environ. Contam. Toxicol. 49, 206-214.

Lotufo, G.R., Nipper, M., Carr, R.S., Conder, J.M., 2009. Fate and toxicity of explosives in sediments. In: Sunahara, G.I., Lotufo, G.R., Kuperman, R.G., Hawari, J. (Eds.) Ecotoxicology of Explosives. CRC Press, Boca Raton, FL, pp. 117-134.

Lytle, T.F., Manning, C.S., Walker, W.W., Lytle, J.S., Page, D.S., 2003. Life-cycle toxicity of dibutyltin to the sheepshead minnow (Cyprinodon variegatus) and implications of the ubiquitous tributyltin impurity in test material. Appl. Organomet. Chem. 17, 653-661.

Manning, C.S., Lytle, T.F., Walker, W.W., Lytle, J.S., 1999. Life-cycle toxicity of bis(tributyltin) oxide to the sheepshead minnow (Cyprinodon variegatus). Arch. Environ. Contam. Toxicol. 37, 258-266.

McCarthy, J.F., Burrus, L.W., Tolbert, V.R., 2003. Bioaccumulation of benzo(a)pyrene from sediment by fathead minnows: effects of organic content, resuspension and metabolism. Arch. Environ. Contam. Toxicol. 45, 364-370.

McCormick, N.G., Feeherry, F.E., Levinson, H.S., 1976. Microbial transformation of 2,4,6-trinitrotoluene and other nitroaromatic compounds. Appl. Environ. Microbiol. 31, 949-958.

Moermond, C.T.A., Roozen, F.C.J.M., Zwolsman, J.J.G., Koelmans, A.A., 2004. Uptake of sediment-bound bioavailable polychlorobiphenyls by benthivorous carp (Cyprinus carpio). Environ. Sci. Technol. 38, 4503-4509.

Nipper, M., Qian, Y., Scott, C.R., Miller, K., 2004. Degradation of picric acid and 2, 6-DNT in marine sediments and waters: the role of microbial activity and ultra-violet 3xposure. Chemosphere 56, 519-530.

Nipper, M., Carr, R.S., Lotufo, G.R., 2009. Aquatic toxicity of explosives. In: Sunahara, G.I., Lotufo, G.R., Kuperman, R.G., Hawari, J. (Eds.), Ecotoxicology of Explosives. CRC Press, Boca Raton, FL, pp. 77-115.

Pennington, J.C., Brannon, J.M., 2002. Environmental fate of explosives. Thermochim. Acta 384, 163-172.

Renoux, A.Y., Sarrazin, M., Hawari, J., Sunahara, G.I., 2000. Transformation of 2,4, 6-trinitrotoluene in soil in the presence of the earthworm Eisenia andrei. Environ. Toxicol. Chem. 19, 1473-1480.

Robidoux, P.Y., Hawari, J., Thiboutot, S., Sunahara, G.I., 2003. Ecotoxicological risk assessment of an explosives-contaminated site. In: Sunahara, G.I., Renoux, A.Y., Thellen, C., Gaudet, C.L., Pilon, A. (Eds.), Enviromental Analysis of Contaminated Sites. John Wiley and Sons, New York, pp. 335-359.

Rodacy, P.J., Walker, P.K., Reber, S.D., Phelan, J., Andre, J.V., 2000. Explosive detection in the marine environment and on land using ion mobility spectroscopy: a summary of field tests. Sandia National Laboratories, Sandia Report SAND2000-0921.

Rosen, G., Lotufo, G.R., 2005. Toxicity and fate of two munitions constituents in spiked sediment exposures with the marine amphipod Eohaustorius estuarius. Environ. Toxicol. Chem. 24, 2887-2897.

Smith, A.A., New, R.A., Wiles, J.E., Kleinow, K.M., 1996. Effect of varying sediment organic carbon content upon the dermal bioavailability and disposition of benzo(a)pyrene in the catfish, Ictalurus punctatus. Mar. Environ. Res. 42, 87-91.

Steevens, J.A., Duke, B.M., Lotufo, G.R., Bridges, T.S., 2002. Toxicity of the explosives 2,4,6-trinitrotoluene, hexahydro-1,3,5-trinitro-1,3,5-triazine, and octahydro1,3,5,7-tetranitro-1,3,5,7-tetrazocine in sediments to Chironomus tentans and Hyalella azteca: low-dose hormesis and high-dose mortality. Environ. Toxicol. Chem. 21, 1475-1482.

Stein, J.E., Hom, T., Varanasi, U., 1984. Simultaneous exposure of English sole (Parophrys vetulus) to sediment-associated xenobiotics: Part 1-Uptake and disposition of ${ }^{14} \mathrm{C}$-polychlorinated biphenyls and ${ }^{3} \mathrm{H}$-benzo[a]pyrene. Mar. Environ. Res. 13, 97-119.

Talmage, S.S., Opresko, D.M., Maxwell, C.J., Welsh, C.J., Cretella, F.M., Reno, P.H. Daniel, F.B., 1999. Nitroaromatic munition compounds: environmental effects and screening values. Rev. Environ. Contam Toxicol. 161, 1-156.

Thorn, K.A., Kennedy, K.R., 2002. ${ }^{15}$ N NMR investigation of the covalent binding of reduced TNT amines to soil humic acid, model compounds, and lignocellulose. Environ. Sci. Technol. 36, 3787-3796. 